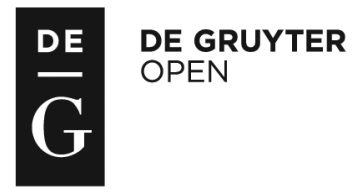

Administration, vol. 65, no. 2 (2017), pp. 165-182

doi: 10.1515/admin-2017-0020

\title{
Political-administrative relations: The role of political advisers
}

\author{
Bernadette Connaughton \\ University of Limerick
}

\begin{abstract}
Ministerial advisers were first formally appointed as support for individual Irish ministers in 1973, and since then their numbers and tasks have considerably expanded. As 'temporary civil servants', they are regarded as both an accepted and criticised feature of executive government. This article focuses on the role of political staff during the period 2011-16 and centres on the period of the economic crisis and its immediate aftermath. It considers themes arising in the international literature that raise questions for the reform of the Irish 'special adviser'. In order to unpack the specifics of the Irish case, the position and function of special advisers are explored through two theoretical perspectives - public adviser bargains and the core executive. It is argued that the special adviser continues to fit somewhat uneasily within the imperatives of the political-administrative system because they are personally appointed by ministers and their selection is determined by the level and type of support required by individual ministers, as opposed to any preordained skills set.
\end{abstract}

Keywords: Special adviser, minister, core executive, public service bargain 


\section{Introduction}

'I see Irish public administration as being stuck between some idealised ... Westminster-type system and some other model it is transitioning towards but never quite getting there.' This comment arose in a conversation with an adviser who served in the Fine Gael/Labour government of 2011-16. Although the reference pertains to the wider systemic features of the political and administrative landscape, one may consider how the role of political advisers, often referred to as special advisers, forms part of the political reform agenda. These 'temporary civil servants' are politically appointed and personally selected by ministers. In several countries, including Ireland, they work alongside the permanent civil service to enhance political support for individual ministers and strengthen the capacity of the executive (Shaw \& Eichbaum, 2015). Political advisers are not bound by the conventions of political impartiality and therefore present as both a solution and a problem in terms of politicaladministrative relations, which in turn presents a challenge for political reform.

This article considers the role of political staff during the period 2011-16. The discussion centres on the period of the economic crisis, its immediate aftermath and the activities of political advisers in the Fine Gael/Labour government elected in February 2011. Firstly, the role of Irish special advisers is contextualised with reference to the reform themes identified in the international literature on political staff. Secondly, the question of how Irish special advisers were included in the government reform agenda is addressed, and their position and function is explored through two theoretical perspectives - public service bargains (PSBs) (Hood \& Lodge, 2006) and core executive studies (Dunleavy \& Rhodes, 1990). The former focuses on issues of political-administrative relations and the introduction of public adviser bargains (PABs) (Shaw \& Eichbaum, 2016). Core executive studies enable a view of advisers' inputs to the functioning of executive government (Craft, 2015; Shaw \& Eichbaum, 2015). A focus on functions, particularly in the context of the economic crisis, expands the discussion beyond the normative considerations of political-administrative relations and in turn encompasses different types of relationships across the executive. It is argued that the special adviser continues to fit somewhat uneasily within the Irish politicaladministrative system because they are unique actors and their appointment is determined by the level and type of support required by individual ministers. 


\section{Ministerial advisers in Westminster systems and beyond}

There are two broad reasons why ministerial advisers are appointed: they contribute to improving the responsiveness of governments and they have the potential to play a strategic role, together with public servants, in designing policies and proposing reforms (OECD, 2010). Advisers are personally appointed by a minister and stand outside the normal hierarchical management structure of a ministry. Concern about controlling their impact and actions is often reflected in concerns about regulating their numbers and introducing instruments such as a code of conduct. In addition, the literature on the countries derived from the Westminster tradition focuses on both advisers' positive input into the policymaking process (Shaw \& Eichbaum, 2015; Yong \& Hazell, 2014) and their controversial association with policy fiascos (Tiernan, 2007). A recent direction in this literature has been to broaden the focus of political adviser research to diverse traditions in Europe and beyond (Di Mascio \& Natalini, 2013; Gouglas, 2015; Öhberg et al., 2017), coupled with attention to cognate literature on policy analysis/public administration models (Craft, 2015). Extending the analysis beyond the Westminster group of countries illustrates more examples of different institutional preferences, how advisers work with civil servants/politicians and what functions they undertake.

In countries of the Westminster genre the special adviser, or 'SpAd', has prompted a robust discussion about how the 'people who live in the dark' exert political influence but also impact on the civil service system and the convention of ministerial responsibility. These issues have encountered a greater degree of scrutiny in the UK (Yong \& Hazell, 2014) than in Ireland. For example, Tony Blair's Labour administration invoked a sceptical attitude towards departmental officials, and senior advisers had the authority to funnel instructions and perform executive functions. This did not lead to productive relationships with civil servants (Laughrin, 2014, p. 82), and these scenarios led to an inquiry by a parliamentary select committee tasked with clarifying these associations (Hood \& Lodge, 2006, p. 128). In contrast, continental European countries and Scandinavia have different ways of structuring partisan policy advice/assistance and political appointees' involvement in governing. This is illustrated by the staffing within ministerial cabinets, political civil servants and special advisers' appointments (De Visscher \& Salomonsen, 2013; Rouban, 2012). 
In the UK and Ireland the historical development of the legal framework regulating public sector labour relations leads back to the Northcote-Trevelyan Report of 1854. A more contemporary interpretation of these issues is the Hood \& Lodge (2006) framework of PSBs, which analyses the relationships between politicians and public servants as the outcome of a political exchange. This highlights the implicit and explicit arrangements in which politicians gain an element of loyalty, expertise and competency from public servants and, conversely, the public servants secure a place in the government structure with commitments regarding protection, responsibility and rewards. As the literature indicates, the advent of advisers has implications for this bargain - they can be viewed as participating in a ménage à trois, with repercussions for political-administrative relations (De Visscher \& Salomonsen, 2013, p. 72), and as another factor leading to the downgrading of civil/public servants' advisory roles (Lodge, 2010, p. 105) in a post New Public Management policy environment. The nature of the bargain applying to political advisers themselves is unclear and, as the commentary above indicates, the literature has generally situated the adviser as an independent variable influencing the core minister/senior official bargain. Shaw \& Eichbaum (2016) scrutinise this through the deployment of the reward, competence and loyalty dimensions of what they call PABs between ministers and the political adviser. Overall, it is accepted that the bargain requires advisers to play an essential supporting role to ministers. In a 24-hour media environment ministers also appoint advisers to take care of their communications and profile. The role is fluid and indefinite, which makes prescriptions for reforming or constructing a PAB less clear-cut.

Further questions, and ones of interest for reform, are how the adviser role manifests in structures and how institutional change affects the senior civil service. For example, in 1984 the Labour government in Australia opted to reconfigure the institution of ministerial offices and employed a large staff complement composed entirely of partisans (Maley, 2015, p. 3). The government acted to assert ministerial control and removed neutral public servants from ministers' offices. In countries of the Napoleonic tradition, however, the adviser entourage resides in ministerial cabinets which are distinct structures and may be characterised by a tendency to exclude civil servants from policy work, as is the case in Belgium. Any move to employ a cabinet model to non-ministerial cabinet systems implies empowering advisers with executive authority and creating 
implications for the secretary general's position in a department. Yet the increase in staff around prime ministers' offices and the UK proposal to develop extended ministerial offices (Cabinet Office, 2013; Yong \& Hazell, 2014) suggest some potential movement towards 'cabinetisation' in non-ministerial cabinet systems, albeit slow and gradual (Gouglas \& Brans, 2016). In addition, Europeanisation, along with the experience of observing the European commissioners' cabinets and liaising with other member state administrations/political parties, broadens awareness of the institutional options available to politicians. In view of this, 'the study of ministerial cabinet system advisers could enlighten other administrative and executive traditions that have been witnessing or dealing with such "cabinetisation" pressures' (Gouglas at al., 2015, p. 1).

A less radical institutional approach is hiring advisers to oversee party business and provide coordination for government within structures at the centre of government (see Peters et al., 2000). To this end, advisers contribute to the operation of the core executive, which acknowledges the broader range of individuals and institutions involved in central policymaking, the key functions for integrating central government policy and the ability to mediate conflict between the various elements of the government machine (Dunleavy \& Rhodes, 1990). Arguably, the core executive focus on function offers the potential to further an analysis of the ministerial adviser who is a coordinator 'type' (see Connaughton, 2010a, 2015). Taking into account the international literature's emphasis on advisers' bargains, locations and functions, the following section provides a context and methodology for exploring the Irish case during 2011-16.

\section{Context and case selection: Drivers for the appointment of political advisers in Ireland}

Political advisers offer potential assistance to improve government responsiveness in terms of politics and policy. However, research indicates that advisers' actions can expose difficulties in addressing the quagmire of responsibilities present in the shadowlands between politics and administration (Eichbaum \& Shaw, 2010; Tiernan, 2007). Therefore, it may be argued that advisers present both a solution and a problem in terms of the design and operation of politicaladministrative relations. In Ireland the routine appointment of advisers was chiefly advanced from 1973 onwards and its organisation was influenced by British Prime Minister Harold Wilson's 'special 
adviser experiment' commencing in the 1960s (see Blick, 2004). The first cohort of Irish political staff were recruited in 1973 amid a realisation that modernisation necessitated political resources and, in turn, led to greater pressures on ministers' workloads. Garret FitzGerald was the only Fine Gael minister to appoint an adviser and he chose an economist, using a rationale that he could make a better contribution in government if someone with different skills would undertake research for him (personal interview).

The appointment of individual special advisers continued until 1992, when a successful electoral result and desire to introduce government reforms motivated Labour to explore new institutional innovations and alternatives in coalition government to a reliance on the civil service for policy advice and management (Farrell, 1994). The result was the introduction of the programme manager system, whereby 'programme managers' worked alongside civil servants and focused on the implementation of an official programme for government both across government departments and within political parties (see O'Halpin, 1997). In addition to the new management structure, ministers also appointed special advisers. The positions coincided until 1997, when the ministerial programme managers were withdrawn by the incoming Fianna Fáil/Progressive Democrats coalition. Only the Taoiseach and Tánaiste had programme managers, and the government reverted to individual advisers serving ministers in a personal capacity and without formalised structures (Connaughton, 2010b). From 1997 onwards, an emphasis was placed on the role of ministers of state (junior ministers), whose numbers substantially increased.

Typically, advisers serve as an 'extension of the minister' in the Irish case (O'Toole \& Dooney, 2009) and work in proximity to civil servants in government departments. Overall, there appear to be two principal drivers for the promotion of special advisers. Firstly, there is the requirement to complement a generalist civil service with more specialist expertise, while also ensuring that civil servants remain politically neutral. Secondly, coalition governments have become regularised in Ireland, bringing with them different party preferences for using staff resources in directing the government agenda and supporting ministers. Both drivers raise important political reform issues in terms of the rules, structures and functions underpinning advisers' roles. The first driver presents issues pertaining to political exchange and to where advisers fit in the relationship between civil servants and ministers. This provides a rationale for exploring the 
concept of a PAB in the Irish context. The second driver, the continuity of coalition governments, highlights the significance of function and coordination across government. This prompts questions about how advisers serve to integrate government business with other actors and structures within the core executive.

Both approaches are now explored in a review of advisers' employment during the 2011-16 Fine Gael/Labour coalition government, in order to unpack their role, how they served the coalition and the implications for reform. The context is elaborated by two interviews in 2008 with a former Taoiseach/minister and a former programme manager. ${ }^{1}$ The analysis of the case is supported by interviews undertaken with two secretaries general and six special advisers who served ministers between 2011-16. ${ }^{2}$

\section{Political advisers and the Fine Gael/Labour coalition, 2011-16}

The Fine Gael/Labour coalition took office in March 2011, following the international markets' loss of confidence in the Irish sovereign and in the aftermath of the adoption of the rescue package from the International Monetary Fund (IMF), in liaison with the European Central Bank (ECB) and European Commission (EC), announced on 28 November 2010. During the election campaign both parties emphasised the significance of reforming the political system and dealing effectively with the crisis. Both factors provided immediate challenges in government. The crisis had placed the overall policy advisory system under critical review (Fitzgerald, 2012), whereby it was acknowledged that the capacity to cope with exposure to risk was undoubtedly shaped by existing national policy frameworks, institutions and processes which did not adequately protect the economy and society (NESC, 2009). Although their roles are varied, the cohort of political staff appointments play a role in this system,

1 The quotes selected are derived from earlier research on special advisers and programme managers for a study on ministerial advisers in the Fianna Fáil/Progressive Democrats government of 2002-07, and from interviews undertaken with advisers in the 2011-16 Fine Gael/Labour government. Interview, Dr Garret FitzGerald (February 2008); interview, former programme manager (February 2008).

2 Secretary general (October 2013); secretary general (October 2013); special adviser, Labour Party (October 2013); special adviser, Fine Gael (October 2013); special adviser, Labour Party (November 2013); special adviser, Labour Party (November 2013); special adviser, Labour Party (November 2013); special adviser, Fine Gael (December 2013). 
raising questions about the effectiveness of their contributions. Cuts to support staff in constituency offices and a promise of ending appointments of unqualified partisan appointees to paid positions in state boards were advocated during the election. Dealing effectively with the crisis was also linked to implementing the troika programme and exiting the bailout.

When questioned in Dáil Éireann on 29 March 2011, the Taoiseach, Enda Kenny, TD, stated that the total number of political appointments would be fewer than in the previous administration, and their remuneration considerably less. He employed a standard response to a question on what his advisers would do: 'The primary function of special advisers will be to secure the achievement of Government objectives and to ensure effective co-ordination in the implementation of the programme for government' (Dáil Éireann, 2011). There was no suggestion of unveiling a radical new departure for the system of political advisers or of a return to the programme manager system.

Both Fine Gael and Labour had previously been in coalition with each other but neither party had been in government since 1997, and few of the TDs had the experience of previously serving as ministers. A number of advisers who held strong qualifications (particularly in the economics sphere) were appointed but the majority did not conform to the definition of an expert within the assigned departmental portfolio. On the Fine Gael side, advisers represented diverse backgrounds. Whereas in relation to Labour, several members of the party held a view that their advisers should be committed to the core values of the party rather than have a minister 'collect them' (personal interview). Unlike the selection criteria of their Fianna Fáil predecessors, the appointment of civil servants to adviser roles was exceptional. Interviewees referred to advisers acting as an 'extension of the minister', 'an extra pair of eyes and hands', 'this time more a thinker than political organiser'; one also stated, '[I] help shape his [the minister] agenda and use my contacts to achieve that goal'.

\section{Public adviser bargains}

This section considers reform of the political adviser in Ireland from the perspective of the $\mathrm{PAB}$ (competence, loyalty, rewards) and the expectation that the number of advisers should be controlled. Although the nature of the bargain for advisers remains unclear, the $\mathrm{PAB}$ concept is a useful lens to unpack the features of their position 
from 2011. Irish advisers are absorbed within existing institutions with two important exceptions - they are exempt from the requirement that civil servants should be appointed on merit and they are not required to be politically neutral. The role is underpinned by legislation in the Public Management Service Act, 1997, and ministers are entitled to two special advisers, whereas the Taoiseach, Tánaiste and leader of a political party may appoint a larger team. A reduced number of political advisers were employed by the Taoiseach in 2011 but all ministers availed of the legislative entitlement to two special advisers, and generally appointed them to 'communications' and 'policy' tasks. Several advisers conforming to the 'policy tsar' title were appointed in portfolios such as health.

One of the challenges in defining the PAB for advisers in Ireland is that it remains somewhat unclear as to what their advisory role is, since it is so varied. This has important implications for the competence aspect of PABs. It would appear the closest that political parties have come to conceptualising this role is the programme manager variant introduced by the Labour Party, or at least Labour had the clearest idea of how the role could be collectively and strategically utilised. Political advisers may offer partisan and/or technical advice, and advisers do not present with a designated skills set. They are selected by ministers for different reasons, and over time some ministers have wanted glorified constituency gofers, policy specialists, experts and predominantly good generalists to cover as many bases as possible (Connaughton, 2010a, p. 354).

For example, an adviser serving between 2011 and 2014 considered his long career working as an education correspondent and critical 'outsider' as potential to adapt to the position. John Walshe's book relating his experience of serving as an adviser to the Labour minister Ruairí Quinn is one of the rare accounts available on the work of Irish special advisers. Walshe stresses that all of his fellow advisers came to the job with a different set of skills and backgrounds, and viewed the task in slightly different ways (Walshe, 2014, p. 12). He appeared to be motivated by the opportunity to use his resources to help a reforming minister make his imprint on policy (Walshe, 2014, p. 13). He contrasts with the more overt party political stance of some appointees, who strive to navigate the tension between the political imperatives of the electoral cycle and the necessity to deliver practical benefits to voters in the short term. Overall, appointments reflect the fact that advisers are 'selected by individual ministers by their assessment of the political support they need' (personal interview). 
This raises an issue for political reform since in reality the role is a fluid and indefinite one, and inevitably this gives rise to the 'mixed bag' of adviser competence. But this is also the nature of the resource across other country systems since it is "nigh on impossible to specify a single definition of the term "political adviser" much less to capture the differences between categories of advisers and their range' (Shaw \& Eichbaum, 2016, p. 2).

In Ireland advisers have a model contract, are subject to the Ethics in Public Office Act, 1995, and are now designated public officials under the Regulation of Lobbying Act, 2015. Through delegated relationships, however, the role of adviser brings political staff into the centre of the governing process, particularly those serving in the Taoiseach and Tánaiste's teams, and across departments and state agencies. Acknowledging the competency of political staff goes beyond a simple exchange of patronage for political loyalty. They learn how government really works, and make contacts and networks that yield capital later on. A downside of the role is the so-called 'lotteries of life' bargain (Shaw \& Eichbaum, 2016, p. 7), in that accepting the role of special adviser involves risk. It is an uncertain career structure that is linked to the minister's time in office, and the job is lost if the minister resigns or is not re-elected/assigned a ministerial portfolio. When Eamon Gilmore resigned as leader of the Labour Party in the aftermath of the local and European elections in 2014, the members of his advisory team also lost their jobs (Gilmore, 2016, p. 289).

The 'after-life' experience of the political adviser raises important questions about an appropriate detachment from the particulars of government business or a gamekeeper role before taking up alternative employment with interest groups or consultants. The Regulation of Lobbying Act, 2015, now provides for a one-year 'cooling-off' period when senior public servants leave office in order to avoid situations where they may directly begin lobbying for the private sector in their previous public service work. Advisers may be subject to a number of post-employment restrictions and may need to request a waiver (that may also be subject to conditions), particularly if their new employer is registered on the Register of Lobbying (see Murphy in this issue for a more extended discussion).

As political advisers are personal appointments, competency will continue to be variable. PABs also raise questions around the tensions between loyalty and responsibility. In terms of loyalty, some may be loyal 'minders' to their minister, some to the party, others may look to see better public policy outcomes through their loyalty to a 
programme, and there are those who object to the term 'partisan' as they see an opportunity to give loyal service to their country. But in the PSB language it is clear that they are not 'trustees' acting as independent adjudicators for the public interest and they are not anonymous (Shaw \& Eichbaum, 2016, p. 13). Loyalty to the minister is expressed in personalist terms, though there have been examples where ministers routinely failed to accept responsibility for their advisers' conduct (Tiernan, 2007). The legislative basis for special advisers is contained within Section 11 of the Public Service Management Act, 1997, whereas an effort to delineate their boundaries is outlined in the Travers report of 2005, where it is made clear that advisers should not become part of the line management of a department. Commentators acknowledge that advisers have a place in the Irish system but it is difficult to secure this in terms of the models/traditional bargain. In terms of wider political reform, the accountability arrangements of special advisers were included in the work of the Independent Panel on Strengthening Civil Service Accountability and Performance, formed in January 2014. The subsequent report included a recommendation to put in place a formal accountability code and mandatory induction training for special advisers. This was incorporated into the Civil Service Renewal Plan, launched at the end of 2014, and while an induction programme was introduced for new advisers in 2016, the details of the proposed special advisers' code of conduct are not in the public domain. Although complicated, a commitment to strengthening advisers' accountability and identifying boundaries of responsibility is necessary to eliminate or minimise undue political influences on public administration, as well as potential conflicts.

Perhaps the most controversial element of the adviser bargain in Ireland is the rewards. Advisers are not a homogeneous group and the most obvious reward in securing the job is remuneration, though there may be limited room for pay acceleration. The Department of Public Expenditure and Reform guidelines stipulate that special advisers should be paid on the principal officer pay scale for the civil service. In 2011 several advisers were paid substantially more than the recommended guidelines, and while they may be high-calibre individuals who previously held much better paid positions, this served as a political own goal. The government underestimated the hostile reaction from the media and the public to the government breaching its own pay caps on advisers in an era of severe cuts to public services and tax hikes. The justification that the salary scales and total pay bill 
were substantially less than those of their Fianna Fáil predecessors rang hollow. In particular, the Labour Party should have foreseen this scenario, anticipated the public reaction to 'kitchen cabinets' and set a more realistic level of remuneration - as opposed to setting a bar for pay and then breaking it. Cost had also been a critical factor in the Labour-led programme manager experiment during the 1990s. As one former programme manager commented in 2008, 'I don't think you will ever see the same scale... folklore in the political mind [was] that the programme managers attracted trouble; why go there and make that hostage to fortune' (personal interview). On the whole, a focus on advisers' pay has shaped discussions in the media regardless of political party or coalition preference for the employment of this actor. It is a knotty issue since advisers may forgo or place on hold security of tenure, increments and pension in anticipation of a future dividend, which may take the form of consultancy, politics, senior public service or a more lucrative private sector position. It remains to be seen whether the Irish political adviser really constitutes a political apprentice, as personified by UK politicians such as David Cameron or Ed Miliband (Reidy, 2016).

\section{Core executive: Coordination and centralisation}

In this section the core executive literature is used to explore advisers' contributions and whether the Irish administration's response conforms with expectations in the literature - namely, that an economic crisis leads to strong political pressures for the use of central authority and the tendency for decision-making to become more politicised (Parrado, 2012). Arguably, the coordination of executive activities in the Fine Gael/Labour administration required greater attention due to the economic crisis, the troika programme and the lasting impact of austerity on policy decisions.

In accordance with Heffernan's (2012) views, the distribution of power within the Irish core executive is both relational and locational, and the political advisers can be divided into performing two main sets of activities: (i) implementation of the programme for government and party/coalition relations, and (ii) shaping the policy agenda in the department and political briefs. Through their services and institutional proximity to ministers, political advisers have the potential to add capacity to shape policy within the core executive. In addition, in the Fine Gael/Labour administration it was critical that coalition relations were managed since it was an environment where 
decisions were hard, and had real electoral and political consequences, whereby audiences on a variety of levels - troika, EU, domestic - had to be satisfied (personal interview). Unlike in 1992, Labour did not have the same bargaining strength in 2011 in choosing which party they would deal with, and they had to accept compromises with Fine Gael on the assignment of key portfolios such as Finance (O'Malley, 2011, pp. 270-1). Labour was keen to have an impact on economic policy and was concerned about the way the Department of Finance had retreated into a silo and acted unilaterally in the period leading up to the EC-ECB-IMF bail-out. During discussions on government formation, senior aides with economic expertise were full members of the party negotiating teams. The resulting agreement was to split the Department of Finance into two departments, each headed by a senior minister. The new Department of Public Expenditure and Reform was given responsibility for spending in the public sector and reform generally (see MacCarthaigh in this issue). An Economic Management Council (EMC) was formed to set economic policy.

Between 2011 and the end of 2013, both coalition parties applied themselves assiduously to the implementation of the troika programme. In his political memoir Eamon Gilmore, the Tánaiste and Minister for Foreign Affairs and Trade during this period, outlined a series of routine weekly meetings that cascaded between levels of key party officials, senior advisers of all ministers, coalition counterparts and Labour ministers, culminating in a meeting between Taoiseach and Tánaiste prior to cabinet (see Gilmore, 2016, pp. 262-4). Each item on the cabinet agenda was discussed and attempts were made to resolve problematic issues between the parties. Senior advisers played a key role in these deliberations and in securing consensus, i.e. prepolitical clearance on sensitive issues which exacerbated coalition tensions. In terms of coordination, the Taoiseach's programme manager led the cabinet committee system from the Department of the Taoiseach, and the Taoiseach's chief of staff focused predominantly on assisting the Taoiseach as head of government and in political coordination. This took the form of an overarching political management role in terms of liaising with personnel in the department and across the executive, party representatives and backbenchers on the impact of policy decisions.

In terms of big policy issues, economic topics acquired a degree of fixation during 2011-16. A substantial part of advisers' time was inevitably required to reduce the potential political fallout from tough financial decisions (particularly around budget time). The EMC 
formed a select membership of party leaders (Taoiseach and Tánaiste), Ministers for Finance and Public Expenditure and Reform, and senior advisers (programme managers), and assumed a different routine to other cabinet sub-committees. A Second Secretary General in the Department of the Taoiseach (reporting to the Tánaiste) was responsible for overseeing its work but the committee was not supported by a parallel senior officials' group, and fewer officials were in attendance (unless by invitation). The EMC was largely driven by advisers and represented a forum for resource exchange and strategic decision-making to facilitate the communication between the two finance ministers, who were central to advancing the requirements of the troika programme and managing public finances. Of significance, both parties sat on equal terms in the EMC and economic decisions were made jointly (Gilmore, 2016; Leahy, 2013; private interviews).

Given the realities of budgetary constraints, the special advisers in the post-2011 administration held more coordination responsibilities generally. This included departmental reporting to the centre of government, namely the Departments of the Taoiseach and of Public Expenditure and Reform, and moving internally/communicating externally policy reform programmes. With a team of assistant secretaries, advisers also participated with ministers directly in the cabinet sub-committee system established to ensure policy deliverables. From the Taoiseach's perspective, the committee system, while not universally liked by Labour, was crucial to policy delivery, and strict deadlines were set for progress reports at monthly meetings (personal interview). The Tánaiste was served by a small team of advisers with a presence in government buildings - a full office was not at their disposal, which contrasted with the Office of Tánaiste, which had existed under Dick Spring's tenure as a Labour Tánaiste in 1992-7.

However, the dominant role of the Taoiseach and Tánaiste's senior advisers and the benefits of this form of coordination were not evident to all. To observers outside the radius of government buildings, instruments such as the EMC represented an accrual of power to the centre, which did not exist in the previous administration (see Leahy, 2013; Walshe, 2014), and Fine Gael appeared to acquire dominance in decision-making. The core EMC group defended its work, however, and ministers and advisers both insisted that the committee did not usurp cabinet but rather avoided paralysis in decision-making processes (Howlin, 2014). The EMC did not leak its deliberations and up to 2014 it considered complex economic and financial issues. This 
included the budget, which inevitably raised tensions between the coalition partners; restructuring the banking system; the government's stance on Europe; and the legacy issues around banking debt. An adviser serving in this government during this period commented that the EMC changed the 'ball game very substantially and the degree of influence advisers have' (personal interview). With the exit of the troika, the EMC's role diminished though it continued to provide a template for organising discussions between ministers and senior advisers on sensitive economic decisions with considerable political ramifications, such as the water charges protest and Irish Water debacle. Overall, the period 2011-14 resurrected the programme manager role less formally and used the cabinet sub-committee system for coordinating new policy, rather than a team of programme managers working across government. Coalition coordination was driven vertically from the centre, where at the top of the pyramid the Taoiseach and Tánaiste's senior team worked together with the resources of the Department of the Taoiseach. Hence, although a distinct inner core of advisers existed, namely chief of staffs and programme managers (in all but name) serving the party leaders at the core executive, there was no reform movement towards cabinetisation or creating a separation from ministerial offices in departments by introducing new structures staffed by advisers.

\section{Conclusion}

Politically appointed staff work closely with ministers and interact with civil servants in departments and across the executive. Their personal selection very much depends on the support required by the particular minister, and advisers deploy their skills accordingly. This is both a strength and a weakness of the system and is challenging for reform. Loyalty and trust are important dimensions in the relationship between Irish ministers and special advisers but are difficult attributes to justify in terms of public appointments. Both the selection and performance of advisers continue to be regarded critically, as there is an expectation that this staffing complement should demonstrably bring added value, relevant expertise to the policymaking process and an ability to learn 'how government works' in a short period of time.

Until Ireland's formal exit from the EC-ECB-IMF programme on 15 December 2013, the troika was an important focus of governance arrangements. The discussion has considered the relevance of how reform has been conceptualised in the international literature on 
advisers to the case of politically appointed advisers in Ireland serving the Fine Gael/Labour coalition in 2011-16. The public service/adviser bargain concept was used to frame an explanation of matters arising in the political exchanges between advisers and their ministers, such as loyalty, competence and responsibility. Issues arising in how advisers work with ministers were incorporated into the government reform agenda led by the Department of Public Expenditure and Reform, namely in terms of considering their accountability relationships. In contrast, the core executive analytical lens facilitated evaluations of the relationships across government, and of how senior advisers worked through particular structures and across parties to drive reform and monitor the implementation of the programme for government.

\section{References}

Blick, A. (2004). People who live in the dark: The history of the special adviser in British politics. London: Politico's.

Cabinet Office. (2013). The civil service reform plan - one year on report. Retrieved from https://www.gov.uk [5 April 2017].

Connaughton, B. (2010a). Glorified gofers, policy experts or good generalists: A classification of the roles of the Irish ministerial adviser. Irish Political Studies, 25 (3), 347-69.

Connaughton, B. (2010b). Ireland. In C. Eichbaum \& R. Shaw (Eds), Partisan appointees and public servants: An international analysis of the role of the political adviser (pp. 151-79). Aldershot: Edward Elgar.

Connaughton, B. (2015). Navigating the borderlines of politics and administration: Reflections on the role of ministerial advisers. International Journal of Public Administration, 38 (1), 37-45.

Craft, J. (2015). Revisiting the gospel: Appointed political staffs and core executive policy coordination. International Journal of Public Administration, 38 (1), 56-65.

Dáil Éireann. (2011). Ceisteanna - Questions: Ministerial staff. 29 March. Dáil Debates, 728 (6).

De Visscher, C., \& Houlberg Salomonsen, H. (2013). Explaining differences in ministerial ménages à trois: Multiple bargains in Belgium and Denmark. International Review of Administrative Sciences, 79 (1), 71-90.

Di Mascio, F., \& Natalini, A. (2013). Analysing the role of ministerial cabinets in Italy: Legacy and temporality in the study of administrative reforms. International Review of Administrative Sciences, 79 (2), 328-46.

Dunleavy, P., \& Rhodes, R. (1990). Core executive studies in Britain. Public Administration, 68 (1), 3-28. 
Eichbaum, C., \& Shaw, R. (Eds) (2010). Partisan appointees and public servants: An international analysis of the role of the political adviser. Aldershot: Edward Elgar.

Farrell, B. (1994). The political role of cabinet ministers in Ireland. In M. Laver \& K. A. Shepsle (Eds), Cabinet ministers and parliamentary government (pp. 73-87). Cambridge: Cambridge University Press.

Fitzgerald, J. (2012). Restoring credibility in policy making in Ireland. Public Money and Management, 2 (1), 27-34.

Gilmore, E. (2016). Inside the room: The untold story of Ireland's crisis government. Dublin: Merrion Press.

Gouglas, A. (2015). Greek ministerial advisers: Policy managers, not experts? International Journal of Public Administration, 38 (1), 15-27.

Gouglas, A., \& Brans, M. (2016). UK extended ministerial offices: On the road to cabinetisation. Retrieved from https://constitution-unit.com/2016/02/09/ukextended-ministerial-offices-on-the-road-to-cabinetisation/ [3 April 2017].

Gouglas, A., Brans, M., \& Jaspers, S. (2015) Political advisers and policy making in ministerial cabinet systems: The case of Belgium, Greece and the European Commission. Paper presented to second ICPP conference, Milan, 1-4 July.

Heffernan, R. (2012). There's no need for the '-isation': The prime minister is merely prime ministerial. Parliamentary Affairs, 66 (3), 636-45.

Hood, C., \& Lodge, M. (2006). The politics of public service bargains. Oxford: Oxford University Press.

Howlin, B. (2014, December 14). Criticism of the EMC is absurd. The Sunday Business Post.

Laughrin, D. (2014). What special advisers do for ministers. In B. Yong \& R. Hazell, Special advisers: Who they are, what they do and why they matter (pp. 61-86). Oxford: Hart Publishing.

Leahy, P. (2013). The price of power - Inside Ireland's crisis coalition. Dublin: Penguin Ireland.

Lodge, M. (2010). Public service bargains in British central government: Multiplication, diversification and reassertion? In M. Painter \& B. G. Peters (Eds), Traditions and public administration (pp. 99-113). Basingstoke: Palgrave Macmillan.

Maley, M. (2015). Patterns of institutional development: Political staff structures in Australia. Paper presented at second ICPP conference, Milan, 1-4 July.

NESC. (2009). Ireland's five-part crisis: An integrated national response [Report no. 118]. Dublin: NESC.

OECD. (2010). Ministerial advisors: Role, influence and management. Paris: OECD Publishing.

O'Halpin, E. (1997). Partnership programme managers in the Reynolds/ Spring coalition, 1993-4: An assessment. Irish Political Studies, 12 (1), 78-91.

Öhberg, P., Munk Christensen, P., \& Niklasson, B. (2017). Administrative politicisation or contestability? How political advisers affect neutral competence in policy processes. Public Administration, 95 (1), 269-85. 
O'Malley, E. (2011). Government formation in 2011. In M. Gallagher \& M. Marsh (Eds), How Ireland voted 2011: The full story of Ireland's earthquake election (pp. 264-82). London: Palgrave.

O’Toole, J. \& Dooney, S. (2009). Irish government today. Dublin: IPA.

Parrado, S. (2012). The executive at work during times of crisis. In M. Lodge \& K. Wegrich (Eds), Executive politics in times of crisis (pp. 197-216). Basingstoke: Palgrave.

Peters, B. G., Rhodes, R. A. W., \& Wright, V. (Eds) (2000). Administering the summit. Basingstoke: Palgrave Macmillan.

Reidy, T. (2016). Candidate selection and the illusion of grassroots democracy. In M. Gallagher \& M. Marsh (Eds), How Ireland voted 2016: The election that nobody won (pp. 47-74). London: Palgrave.

Rouban, L. (2012). Politicisation of the civil service. In B. G. Peters \& J. Pierre (Eds), Handbook of public administration (2nd ed., pp. 380-91). London: Sage.

Shaw, R. \& Eichbaum, C. (2015). Follow the yellow brick road: New directions in studying political advisers in executive government. International Journal of Public Administration, 38 (1), 1-3.

Shaw, R., \& Eichbaum, C. (2016). Politicians, political advisers and the vocabulary of public services bargains: Speaking in tongues? Public Administration. Advance online publication. doi: 10.1111/padm.12281

Tiernan, A. (2007). Power without responsibility. Sydney: UNSW Press.

Travers, J. (2005). Interim report on certain issues of management and administration in the Department of Health and Children associated with the practice of charges for persons in long stay health care in health board institutions and related matters. Dublin: The Stationery Office.

Walshe, J. (2014). An education: How an outsider became an insider - and learned what really goes on in Irish government. Dublin: Penguin Ireland.

Yong, B., \& Hazell, R. (2014). Special advisers: Who they are, what they do and why they matter. Oxford: Hart Publishing. 